\title{
Bone marrow transplantation: Graft versus host disease and oral changes
}

\section{Transplante de medula óssea: doença enxerto versus hospedeiro e alterações orais}

\begin{abstract}
Purpose: This study aimed to evaluate the prevalence of oral changes and their association with graft versus host disease (GVHD) in patients undergoing bone marrow transplantation (BMT).

Methods: The sample consisted of 51 BMT patients. A questionnaire was used to collect data on age, gender, disease, type and time of transplant, cell origin, and GVHD occurrence. The extraoral and intraoral clinical examinations were performed by specialized professionals.

Results: Systemic GVHD was observed in $32.5 \%$ of the allogeneic transplant patients, and all of the patients with GVHD had oral manifestations. There was a statistically significant association between systemic GVHD and oral manifestations $(P<0.001)$.

Conclusion: Given the relatively high prevalence of oral changes associated with GVHD in patients undergoing BMT, this study confirms the need to consider dental aspects in the examination, diagnosis, treatment and prognosis of possible complications after BMT.
\end{abstract}

Key words: Bone marrow transplantation; oral manifestations

\section{Resumo}

Objetivo: Este estudo objetivou avaliar a prevalência de alterações orais e sua associação com a doença enxerto versus hospedeiro $(\mathrm{DEVH})$ em pacientes submetidos a transplante de medula óssea (TMO).

Metodologia: A amostra consistiu de 51 pacientes. Por meio de questionário, foram coletados dados sobre idade, sexo, doença, tipo e tempo de transplante, origem das células e ocorrência da DEVH. Foram realizados exames clínicos extra e intraoral por profissionais especializados.

Resultados: DEVH sistêmica foi observada em 32,5\% dos pacientes transplantados alogênicos, todos apresentando manifestações orais. Também houve uma associação estatisticamente significante entre DEVH sistêmica e manifestações orais $(P<0,001)$.

Conclusão: Diante da prevalência de alterações orais relativamente alta associada à DEVH em pacientes submetidos ao TMO, o presente estudo confirma a necessidade de se considerar a odontologia no exame, diagnóstico, tratamento e prognóstico de possíveis complicações após o transplante de medula óssea.

Palavras-chave: Transplante de medula óssea; doença enxerto-hospedeiro; manifestações orais

\author{
Emeline das Neves de Araújo Lima a \\ Maria Zélia Fernandes ${ }^{b}$ \\ Maria Ângela Fernandes Ferreira ${ }^{a}$ \\ Cassiano Francisco Weege Nonaka ${ }^{\circ}$ \\ Roseana de Almeida Freitas ${ }^{\circ}$ \\ Ana Miryam Costa de Medeiros a
}

- Dental School, Federal University of Rio Grande do Norte, Natal, RN, Brazil

b Center for Bone Marrow Transplant, Natal Hospital Center/Institute of Onco-Hematology, Natal, RN, Brazil

\section{Correspondence:}

Ana Miryam Costa de Medeiros

Universidade Federal do Rio Grande do Norte Departamento de Odontologia

Av. Senador Salgado Filho, 1787 - Lagoa Nova Natal, RN - Brazil

59056-000

E-mail: emelinelima@hotmail.com

Received: October 11, 2011

Accepted: January 13, 2012

Conflict of Interests: The authors state that there are no financial and personal conflicts of interest that could have inappropriately influenced their work.

Copyright: (c) 2011 Lima et al.; licensee EDIPUCRS. This is an Open Access article distributed under the terms of the Creative Commons AttributionNoncommercial-No Derivative Works 3.0 Unported License. 


\section{Introduction}

Bone marrow transplantation (BMT) is the therapeutic modality used in the treatment of many benign or malignant, inherited or acquired hematologic diseases $(1,2)$. BMT is characterized by the removal of stem cells from the donor, which may be the patient himself (autologous transplant) or another compatible donor (allogeneic transplant), and the infusion of these cells into the patient after a conditioning period (2-4). Progenitor cells infused into the bloodstream are implanted in the bone marrow, promoting hematopoietic reconstitution $(4,5)$.

The annual frequency of performing BMT with high success rates are growing exponentially due to a greater knowledge of the human histocompatibility system and accurate examinations in the selection of bone marrow donors. However, graft versus host disease (GVHD) still represents one of the most common complications after allogeneic transplant (3).

GVHD is a complication that occurs through the activation of $\mathrm{T}$ cells in response to molecules from the major histocompatibility complex (MHC) after an allogeneic histocompatible BMT. Donated T cells recognize molecules from the host tissue as foreign (3-5). The incidence of GVHD varies from 6 to $80 \%$ according to patient age, donor type, stem cell source, graft manipulation and use of lymphocyte infusions after the transplant (6).

The clinical manifestations of GVHD can affect the skin, liver, gastrointestinal tract and/or lymphoid system $(3,4)$ and may present an acute or chronic form (5). Oral lesions may be associated with GVHD and are present in 25 to $70 \%$ of the cases (6-8). They are characterized by erythematous areas, ulcers and/or pain, and the most commonly involved regions are the buccal mucosa and tongue (9). In addition, some studies have shown that the oral mucosa of BMT recipients represents a favorable environment for the development of various manifestations, such as mucositis, lichenoid reaction, fungal and herpetic infections, hairy leukoplakia, pigmentation, thrombocytopenic purpura, and spontaneous gingival alterations independent of dental biofilm and malignant neoplasms $(2,10,11)$. Thus, this association emphasizes the importance of dentistry in the diagnosis and clinical management of these patients.

Taking into account the increasing inclusion of BMT as an indication for the treatment of malignant and nonmalignant hematologic diseases and the frequent occurrence of GVHD with manifestations in the oral cavity, this study aims to evaluate the prevalence of oral abnormalities in these patients and verify their association with GVHD in cases of allogeneic BMT.

\section{Methodology}

The project was approved by the "Research Ethics Committee of the Federal University of Rio Grande do Norte" in accordance with national and international guidelines and regulations.
Study design and sample

This study is characterized as a prevalence study with a cross-sectional design. The population was represented by all bone marrow transplanted patients registered from 2004 to 2011 at a referral center for BMT in Natal, Rio Grande do Norte state, Brazil. There were 63 patients registered during the selected period. We included those who showed good physical and psychological states so that they could answer a questionnaire and undergo a clinical examination of the oral cavity upon authorization by the attending physician. The study excluded individuals who showed unfavorable physical and/or psychological conditions. Thus, the final sample consisted of 51 patients who sought dental treatment at the Clinic of Oral Diagnosis in the Dentistry Department of the Federal University of Rio Grande do Norte.

\section{Data collection}

A questionnaire was used to collect data on age, gender and disease, as well as information related to the transplant (type, time of transplantation, and source of the transplanted cells) and complications during treatment, such as the occurrence of systemic GVHD, which were previously diagnosed by the medical team as functional complications of the skin, liver, gastrointestinal tract or lymphoid system.

Patients underwent an extra- and intraoral clinical examination to identify possible injuries. The evaluation was conducted by two professionals, who were previously trained to identify the following conditions: mucositis, lichenoid reaction, thrombocytopenic purpura, pigmentation, candidiasis, and gingival changes unrelated to dental biofilm. Symptoms such as reduced salivary flow and xerostomia were excluded from analysis because they are already well recognized features in the literature.

The statistical data analysis was performed using the SPSS program (Statistical Package for the Social Sciences), version 17.0. Categorical variables are presented as absolute and relative frequencies and were subjected to analysis by chi-square tests. To analyze the frequency of oral abnormalities at different times after BMT, the continuous variable "time" was categorized as " $\leq 100$ days" and " $>100$ days". Thus, we could analyze the most frequent period of oral manifestations. A significance level of $5 \%(\alpha=0.05)$ was set for all tests.

\section{Results}

There was no significant predominance for gender, with a slight tendency towards females $(27 / 51 ; 53 \%)$ over males $(24 / 51 ; 47 \%)$. Patient age ranged from 5 to 54 years old, with an average of 34.6 years old. There was a predominance of acute myeloid leukemia $(24 / 51 ; 47 \%)$, followed by chronic myeloid leukemia $(8 / 51 ; 16 \%)$ and multiple myeloma $(6 / 51 ; 12 \%)$.

With regard to the transplants performed, there was a predominance of the allogeneic type $(40 / 51 ; 78 \%)$. The time of the transplant ranged from 0 to 1,291 days, with an average of 370.4 days. 
Graft versus host disease (GVHD) was observed in $32.5 \%(13 / 40)$ of the patients undergoing allogeneic BMT (Table 1), and approximately half of all patients presented oral manifestations $(25 / 51 ; 49 \%)$. Some patients had more than one type of lesion in the oral cavity. The observed manifestations are listed in Table 2 and shown in Fig. 1.

Table 2. Distribution of oral abnormalities in patients undergoing allogeneic BMT according to the time of transplantation at the ION/Natal Hospital Center, Brazil, Natal-RN, 2011.
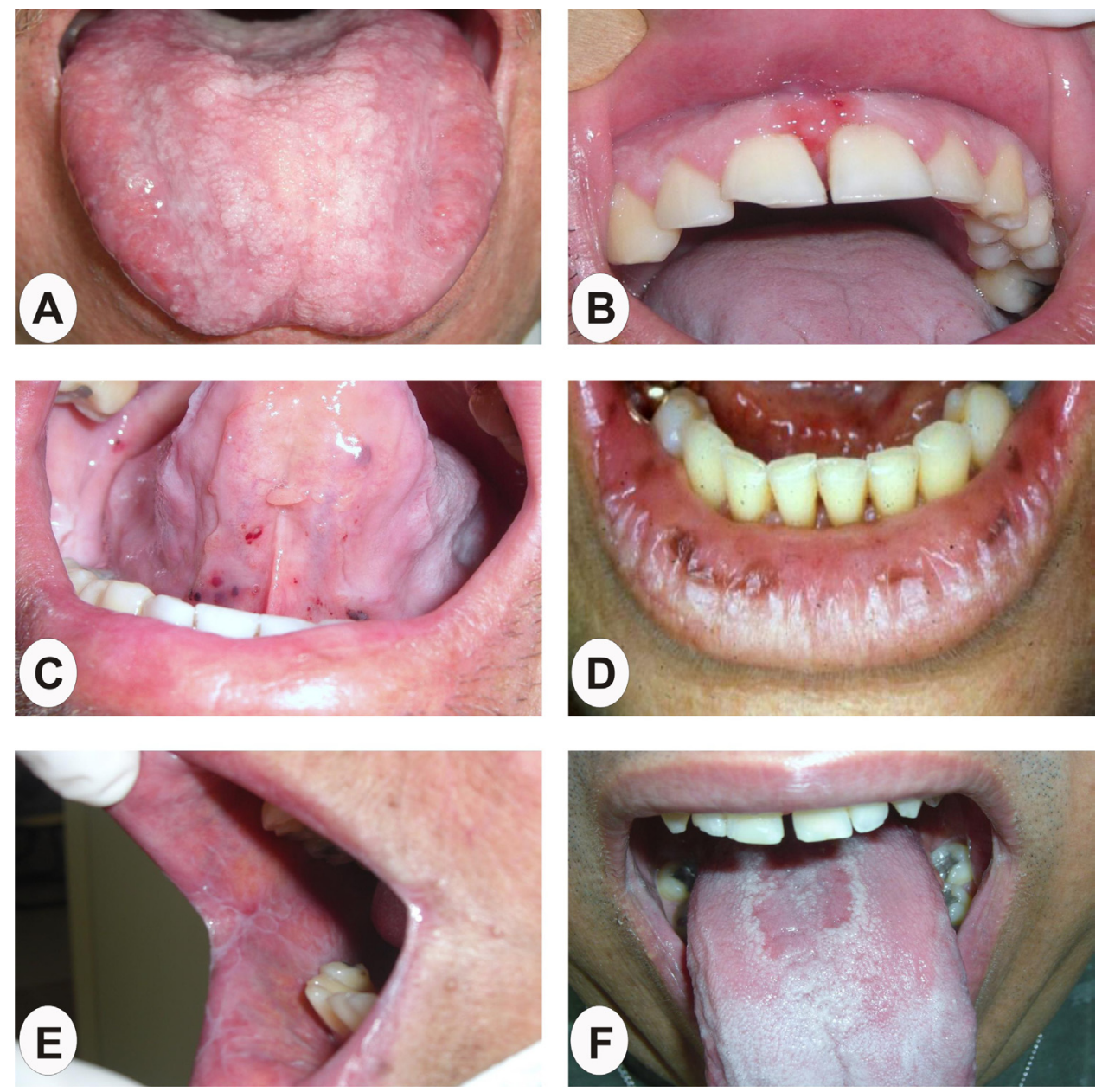

Table 1. Distribution of cases according to sex and the presence of GVHD in patients undergoing allogeneic bone marrow transplantation in the ION/Natal Hospital Center, Brazil, Natal-RN, 2011.

\begin{tabular}{lcccccc}
\hline & \multicolumn{4}{c}{ Gender } & \multicolumn{2}{c}{ Total } \\
\cline { 2 - 6 } GVHD & \multicolumn{2}{c}{ Male } & \multicolumn{2}{c}{ Female } & & \\
\cline { 2 - 6 } & $\mathbf{n}$ & $\%$ & $\mathrm{n}$ & $\%$ & $\mathrm{n}$ & $\%$ \\
\hline Not & 10 & 25 & 17 & 42.5 & 27 & 67.5 \\
Yes & 8 & 20 & 5 & 12.5 & 13 & 32.5 \\
Total & 18 & 45 & 22 & 55 & 40 & 100.0 \\
\hline
\end{tabular}

Fig. 1. Oral manifestations of BMT patients. (A) Mucositis in the tongue, with evident areas of erythema and ulcerations. (B) Gingival change characterized by the presence of inflammation and an erythematous area; note the absence of dental biofilm.(C) Thrombocytopenic purpura represented by red and purple pigmentation on the mouth floor. (D) Brownish pigmentation on the lower lip. (E) Lichenoid reaction in the buccal mucosa. (F) Atrophic candidiasis as represented by a red area with white edges on the dorsum of the tongue. 
Table 3. Distribution of oral manifestations according to the occurrence of GVHD at the ION/Natal Hospital Center, Brazil, NatalRN, 2011.

Table 4. Distribution of oral manifestations according to the type of transplant and origin of the cells at the ION/Natal Hospital Center, Brazil, Natal-RN, 2011.

\begin{tabular}{|c|c|c|c|c|c|}
\hline \multirow[b]{2}{*}{ GVHD } & \multicolumn{2}{|c|}{ Oral Manifestations } & \multirow[b]{2}{*}{$\begin{array}{l}\text { Total } \\
\mathrm{n}(\%)\end{array}$} & \multirow[b]{2}{*}{$\chi^{2}$} & \multirow[b]{2}{*}{$P$} \\
\hline & $\begin{array}{c}\text { Absent } \\
\text { n (\%) }\end{array}$ & $\begin{array}{c}\text { Present } \\
\text { n (\%) }\end{array}$ & & & \\
\hline Absent & $26(68.4)$ & $12(31.6)$ & $38(100.0)$ & 18.145 & $<0.001^{*}$ \\
\hline Present & $0(0.0)$ & $13(100.0)$ & $13(100.0)$ & & \\
\hline
\end{tabular}

* Chi-square test.

\begin{tabular}{|c|c|c|c|c|}
\hline \multirow[b]{2}{*}{ Parameters } & \multicolumn{2}{|c|}{ Oral manifestations } & \multirow[b]{2}{*}{$\chi^{2}$} & \multirow[b]{2}{*}{$P$} \\
\hline & $\begin{array}{c}\text { Absent } \\
\text { n (\%) }\end{array}$ & $\begin{array}{c}\text { Present } \\
\text { n (\%) }\end{array}$ & & \\
\hline Type of transplant & & & 2.654 & $0.103^{*}$ \\
\hline Allogeneic & 18 (69.2) & $22(88.0)$ & & \\
\hline Autologous & $8(30.8)$ & $3(12.0)$ & & \\
\hline Total: n(\%) & $26(100.0)$ & $25(100.0)$ & & \\
\hline \multicolumn{5}{|l|}{ Cell origin } \\
\hline Bone marrow & 11 (42.3) & $21(52.0)$ & 0.481 & $0.488^{*}$ \\
\hline Peripheral blood & $15(57.7)$ & $19(48.0)$ & & \\
\hline Total: n(\%) & $26(100.0)$ & $25(100.0)$ & & \\
\hline
\end{tabular}

* Chi-square test.
In all cases of allogeneic transplants with GVHD, we observed oral manifestations. There was a significant association between the presence of changes in the oral cavity and GVHD in the allogeneic transplants $(\mathrm{P}<0.001)$ (Table 3). The results regarding the type of transplant performed and the origin of the transplanted cells are shown in Table 4 . There was no statistically significant association between these variables.

\section{Discussion}

After BMT, some patients develop changes in the oral cavity, often in association with GVHD (12). Risk factors, such as prolonged hospitalization, changes in the oral microbiota, the use of broad-spectrum antibiotics, preexisting dental infections, poor oral hygiene and nutritional status, may contribute to the increased incidence and severity of oral complications in BMT patients (13). Because the oral cavity has a large number of microorganisms, it can serve as a source of infection during severe myelosuppression, aggravating the clinical condition of the patients (1).

In the present investigation, the most frequent diseases presented by the patients were acute myeloid leukemia, chronic myeloid leukemia, and multiple myeloma, in agreement with the literature with regard to the major diseases with an indication for BMT (2). The most common type of transplant was allogeneic, with a similar use of cells from the peripheral blood and bone marrow. This profile of the patients with an indication for BMT is consistent with that in the literature (14). The low number of autologous transplants was expected because this type of transplantation is still being implemented in the center where the study was performed, while the allogeneic transplantations are more frequent. This bias is a limitation of the present study and might have impacted some aspects of the results.
In the present study, graft versus host disease (GVHD) was observed in $32.5 \%$ of patients, with most cases presenting the chronic form without an association with the origin of the transplanted cells. The dental literature also reports an incidence of 30 to $70 \%$ for this disease after allogeneic BMT, with a predominance of the chronic form $(2,4,5)$. Oral changes were found in $49 \%$ of all patients, sometimes as part of GVHD, which is similar to a previous report (15). The graft versus host disease was assessed only in relation to gender because the study group did not show large variations in the other variables.

Despite affecting a small percentage of patients, oral mucositis represents the most frequent manifestation in the study. Such damage is reported as being the most prevalent adverse effect in cancer patients under various treatment modalities (16), including BMT $(14,17,18)$. Therefore, in such cases, mucositis can be recognized as toxicity related to the conditioning regimen (19). However, in patients with GVHD, this manifestation characterizes the pathophysiology of the disease and is not related to the conditioning treatment (15).

Pereira Pinto et al. (18) evaluated the clinical aspects of the oral mucosa in children with acute lymphoblastic leukemia after prophylactic mouthwash with chlorhexidine $0.12 \%$. They observed a significant decrease in the incidence of oral mucositis and ulcerations, suggesting the systematic use of a preventive protocol for these patients. Another treatment option is phototherapy, which has shown good results for reducing pain after BMT (16).

The lichenoid reaction and fungal infection were less frequent oral changes. Although the lichenoid reaction is considered one of the main diagnostic features of GVHD and is widely observed in BMT patients (6), this change occurred in only two patients in this sample, both of whom presented clinical signs of GVHD. Fungal infections were previously reported in 15 to $56 \%$ of patients undergoing 
BMT (20), but the early diagnosis of oral candidiasis is often hindered by the presence of other injuries, such as mucositis. Thus, systemic prophylaxis is still recommended in states of immunosuppression. In the BMT Center where this study was conducted, the clinical protocol includes prophylactic antifungal medications, which was most likely reflected in the low occurrence of candidiasis (4\%).

Regarding the type of transplant performed, the highest incidence of oral abnormalities is reported in cases of allogeneic BMT, often related to DECH $(4,21)$. Confirming these findings, the majority of oral lesions in this investigation occurred in cases of allogeneic transplants (88\%). However, there was no statistically significant association between oral abnormalities and the type of transplant performed. The period of development for oral abnormalities can range from the first day after BMT up to long post-transplant periods of time (13). However, late manifestations are more frequent, especially when associated with the presence of DECH (22). In the studied sample, a higher prevalence of oral lesions was found after the 100th day of transplantation, which suggests a tendency to chronic or late manifestations in the oral cavity (4).

With respect to the origin of the transplanted cells, $52 \%$ of the oral abnormalities affected patients transplanted with bone marrow cells, and $48 \%$ were in patients undergoing transplantation with peripheral cells. Similarly to the type of transplant, no significant association was found between oral abnormalities and the origin of the transplanted cells. In a randomized study that compared BMT with cells from the bone marrow and from peripheral blood (23), oral abnormalities were the most common manifestations of chronic GVHD in BMT with bone marrow cells and the second most common (after skin) in BMT with peripheral cells, demonstrating a high prevalence of oral manifestations.
When analyzing a possible association between oral abnormalities and presence of GVHD, we observed that all GVHD patients had oral manifestations. This result confirms that oral GVHD may be considered a potential risk factor for the development of different injuries in the mouth following allogeneic BMT $(24,25)$. A significant association between oral changes and GVHD shows the importance of adopting a protocol for the prevention and long-term monitoring of patients, with a focus on improving the oral health status and controlling the bacterial flora. A periodic evaluation of the oral cavity is recommended to prevent the occurrence of severe oral changes, allow the early diagnosis of possible systemic complications and GVHD, ensure prompt treatment and reduce the burden of these diseases.

\section{Conclusions}

The present results show a relatively high frequency of oral abnormalities in patients undergoing BMT, most commonly represented by mucositis, gingival changes unrelated to dental biofilm, and thrombocytopenic purpura. These manifestations were more common in allogeneic transplantations, with a slight tendency towards a late manifestation (more than 100 days post-transplant), which is the same period seen in most episodes of GVHD. The late onset observed for both GVHD and oral manifestations can be explained by the high efficacy of the treatment protocol adopted, thereby preventing the lesions during the acute phase. A significant association between GVHD and the presence of changes in the oral cavity shows the need to consider this site a key organ for the examination, diagnosis, treatment and prognosis of possible complications of bone marrow transplantation. hematopoietic cell transplantation: diagnosis and management. Support Care Cancer 2000;8:353-65.

2. Flowers MED, Kansu E. Late complications of hematopoietic stem cell transplantation. Medicina (Ribeirão Preto) 2000;33:415-32.

3. Treister NS, Stevenson K, Kim H, Woo S-B, Soiffer R, Cutler C. Oral chronic-versushost disease scoring using the NIH consensus criteria. Biol Blood Marrow Transplant 2010;16:108-14.

4. Martin PJ. Biology of chronic graft-versus-host disease: implications for future therapeutic approach. Keio J Med 2008;57:177-83.

5. Ferrara JLM, Levine JE, Reddy P, Holler E. Graft-versus-host disease. Lancet 2009;373:1550-61.

6. Lee SJ, Flowers ME. Recognizing and managing chronic graft-versus-host disease. Hematology Am Soc Hematol Educ Program 2008:134-41.

7. Sato M, Tokuda N, Fukumoto T, Mano T, Sato T, Ueyama Y. Immunohistopathological study of the oral lichenoid lesions of chronic GVHD. J Oral Pathol Med 2006;35:33-6.

8. Hull KM, Kerridge I, Schifter M. Long-term oral complications of allogeneic haematopoietic SCT. Bone Marrow Transplant [serial on the Internet]. Epub 2011 Mar 28. [cited 2011]. Available from: http://www.nature.com/bmt/journal/vaop/ncurrent/full/bmt201 163a.html

9. Imanguli MM, Alevizos I, Brown R, Pavletic SZ, Atkinson JC. Oral graft-versus-host disease. Oral Dis 2008;14:396-412.

10. Nicolatou-Galitis O, Kitra V, Van Vliet-Constantinidou C, Peristeri J, Goussetis E, Petropoulos $\mathrm{D}$ et al. The oral manifestations of chronic graft-versus-host disease (cGVHD) in paediatric allogeneic bone marrow transplant recipients. J Oral Pathol Med 2001;30:148-53. 
11. Al-Mohaya MA, Darwazeh A, Al-Khudair W. Oral fungal colonization and oral candidiasis in renal transplant patients: the relationship to Miswak use. Oral Surg Oral Med Oral Patol Oral Radiol Endod 2002;93:455-60.

12. Kashiwazaki H, Matsushita T, Sugita J, Shigematsu A, Kasashi K, Yamazaki Y et al. Professional oral health care reduces oral mucositis and febrile neutropenia in patients treated with allogeneic bone marrow transplantation. Support Care Cancer [serial on the Internet]. Epub 2011 Feb 15. [cited 2011]. Available from: http://www.springerlink.com/ content/q32125725h60lr87/.

13. Melkos AB, Massenkeil G, Arnold R, Reichart PA. Dental treatment prior to stem cell transplantation and its influence on the prost-transplantation outcome. Clin Oral Invest 2003; 7:113-15.

14. Sonis ST, Oster G, Fuchs H, Bellm L, Bradford WZ, Edelsberg J et al. Oral mucositis and the clinical and economic outcomes of hematopoietic stem-cell transplantation. J Clin Oncol 2001;19: 2201-05.

15. Sugita J, Matsushita T, Kashiwazaki H, Kosugi M, Takahashi S, Wakasa K, et al. Efficacy of folinic acid in preventing oral mucositis in allogeneic hematopoietic stem cell transplant patients receiving MTX as prophylaxis for GVHD. Bone Marrow Transplant 2011 [serial on the internet]. Epub 2011 Mar 21. [cited 2011]. Available for: http://www.nature.com/bmt/journal/vaop/ncurrent/full/bmt201153a.html.

16. Hodgson BD, Margolis DM, Salzman DE, Eastwood D, Tarima S, Williams LD et al. Amelioration of oral mucositis pain by NASA near-infrared light-emitting diodes in bone marrow transplant patients. Support Care Cancer [serial on the internet]. Epub $2011 \mathrm{Jul} 3$. [citet 2011 1]. Available for: http://www.springerlink.com/content/l247w067270721 12/.

17. Robien K, Schubert MM, Bruemmer B, Lloid ME, Potter JD, Ulrich CM. Predictors of oral mucositis in patients receiving hematopoietic cell transplants for chronic myelogenous leukemia. J Clin Oncol 2004;22:1268-75.

18. Pereira Pinto L, de Souza LB, Gordón-Núñez MA, Soares RC, de Brito Costa EM, de Aquino $A R$ et al. Prevention of oral lesions in children with acute lymphoblastic leukemia. Int J Pediatr Otorhinolaryngol 2006;70:1847-51.

19. Rubenstein EB, Peterson DE, Schubert M, Keefe D, McGuire D, Epstein J et al. Mucositis Study Section of the Multinational Association for Supportive Care in Cancer; International Society for Oral Oncology. Clinical practice guidelines for the prevention and treatment of cancer therapy-induced oral and gastrointestinal mucositis. Cancer 2004;100: 2026-46.

20. Epstein JB, Hancock PJ, Nantel S. Oral candidiasis in hematopoietic cell transplantation patients: an outcome-based analysis. Oral Surg Oral Med Oral Pathol Oral Radiol Endod 2003;96:153-63.

21. Elad S, Zeevi I, Or R, Resnick IB, Dray L, Shapira MY. Validation of the National Institutes of Health (NHI) scale for oral chronic graft-versus-host disease (cGVHD). Biol Blood Marrow Transplant 2010;16: 62-9.

22. Orti-Raduan ES, Nunes AJ, Oliveira DT, Lara VS, Taveira LA. Quantitative analysis of Langerhans' cells in oral chronic graft-vs.-host disease. J Oral Pathol Med 2009;38:132-7.

23. Flowers ME, Parker PM, Johnston LJ, Matos AV, Storer B, Bensinger WI et al. Comparison of chronic graft-versus-host disease after transplantation of peripheral blood stem cells versus bone marrow in allogeneic recipients: long-term follow-up of a randomized trial. Blood 2002;100:415-9.

24. Mawardi H, Elad S, Correa ME, Stevenson K, Woo SB, Almazrooa S et al. Oral epithelial dysplasia and squamous cell carcinoma following allogeneic hematopoietic stem cell transplantation: clinical presentation and treatment outcomes. Bone Marrow Transplant $2011 ; 46: 884-91$.

25. Montebugnoli L, Gissi DB, Marchetti C, Foschini MP. Multiple squamous cell carcinomas of the oral cavity in a young patient with graft-versus-host disease following allogenic bone marrow transplantation. Int J Oral Maxillofac Surg 201 1;40:556-8. 